\title{
Article \\ Kochia (Kochia scoparia) and Wild Oat (Avena fatua) Intraspecific and Interspecific Interference
}

\author{
Shaun M. Sharpe
}

Citation: Sharpe, S.M. Kochia (Kochia scoparia) and Wild Oat (Avena fatua) Intraspecific and Interspecific Interference. Agronomy 2021, 11, 62. https://doi.org/10.3390/agronomy 11010062

Received: 15 December 2020 Accepted: 28 December 2020 Published: 30 December 2020

Publisher's Note: MDPI stays neutral with regard to jurisdictional clai$\mathrm{ms}$ in published maps and institutional affiliations.

Copyright: (c) 2020 by Her Majesty the Queen in Right of Canada as represented by the Agriculture and Agri-Food Canada; licensee MDPI, Basel, Switzerland. This article is an open access article distributed under the terms and conditions of the Creative Commons Attribution (CC BY) license (https://creativecommons. org/licenses/by-nc-nd/4.0/)
Saskatoon Research and Development Centre, Agriculture and Agri-Food Canada, 107 Science Place, Saskatoon, SK S7N 0X2, Canada; shaun.sharpe@canada.ca

\begin{abstract}
Kochia (Kochia scoparia) and wild oat (Avena fatua) are highly problematic western Canadian weeds. Wild oat is widely distributed and has been a long-standing agricultural pest across Manitoba, Saskatchewan, and Alberta. Kochia populations are patchy and occur more frequently within the southern regions of the Prairie provinces. Kochia is exhibiting an ever-evolving, aggressive, herbicide resistance survival strategy which may facilitate range expansion. The experimental objective was to study the interspecific and intraspecific interference between wild oat and kochia. The study was developed with the context of kochia tumbleweeds travelling and depositing seed within wild oat infestations. Greenhouse experiments were conducted in Saskatoon, SK. The experimental design was a two factor factorial arranged as a randomized complete block. The main factors were kochia and wild oat pot density at either 0,1 , or 2 plants per pot. Treatment combinations resulted in species ratios of 1:1, 2:1, 1:2, and 2:2, with single species controls. Kochia biomass was reduced by $>70 \%$ after 3 months of competition with a single wild oat plant. Wild oat biomass was consistently impacted by intraspecific competition, demonstrating a 25 to $50 \%$ reduction at the trial end. Kochia interspecific interference with wild oat at a 2:1 ratio did reduce wild oat biomass by $50 \%$ but this trend was not consistent across experimental runs. Kochia dispersal through wild oat infestations should induce competitive stress when crop competition is considered. Three-species interference patterns to include western Canadian crops require additional study.
\end{abstract}

Keywords: ecology; competition; plant heights; biomass

\section{Introduction}

Annual crops are an economically important component of western Canadian agriculture. The Prairie provinces of Manitoba, Saskatchewan, and Alberta produced 9.3 Mha of oilseeds, 13.1 Mha of cereals, and 3.4 Mha of pulses in 2019 [1]. Current western Canadian annual crop production is characterized by the adoption of zero tillage. Specialized machinery is used to minimize soil disturbance when applying seeds and fertilizer while weeds are primarily controlled with herbicides [2]. Crops are planted in the spring and herbicide inputs applied prior to crop seeding and atop the crop, post-emergence, to prevent earlyseason weed interference [3]. Annual production and the historical widespread reliance on herbicides for weed management have led to the evolution of several herbicide-resistant, early successional species within the weed community [4-6]. Two species of particular concern are wild oat (Avena fatua L.) and kochia (Kochia scoparia L.).

Wild oat has been a long-standing threat to crop production on the Canadian Prairies. Wild oat control recommendations date back to the early 1900s [7]. Its continuous dominant place within the weed community has been documented by five federally supported quantitative surveys from 1974 onward [8-14]. Across Saskatchewan ecoregions, wild oat occupied the highest frequency of fields within the boreal transition zone (58.3\%) and aspen parkland ecoregion (53.8\%), followed by the moist mixed grassland ecoregion (42.8\%) and mixed grassland ecoregion (33.7\%) [14]. Wild oat populations are also particularly high among boundary transitions into fields [15]. Wild oats sustained presence has been aided 
by complex seed dormancy [16-18], low yearly microbial decay [19], and the development of resistance to several commonly used herbicides [4]. Wild oat populations have notably demonstrated resistance to Group 1 (cyclohexanedione, aryloxyphenoxy-propionate and phenylpyrazoline chemical families) and Group 2 (imidazolinones imazamethabenz and imazamox, and the sulfonylaminocarbonyl-triazolinone flucarbazone) [20-22]. Wild oat is highly competitive with cereals and influenced by seedling number [23] and emergence timing [24]. Canola has demonstrated wild oat interference tolerance, with mixtures up to 1:3 (wild oat/canola), while heavier infestations (1:1) begin to induce irrevocable yield loss broadly across cultivars [25].

Kochia is an annual, late maturing, patch forming tumbleweed [26]. Kochia patch stabilization within western Canadian annual cropping systems is likely a consequence of its auto-allelopathy [27], adaptation as a pioneer species [5] including wind-mediated dispersal into disturbed areas, adaptation to saline environment [28], development of herbicide resistance [29-31], and reliance of herbicides for weed management and to halt secondary succession. Kochia is exhibiting an ever-evolving, aggressive, herbicide resistance survival strategy starting in 1988 [32]. Resistance for Group 2 (thifensulfuron and tribenuron) [33,34], Group 9 (glyphosate) [29,30,34], and Group 4 (dicamba), including triple-resistant kochia populations [31] have been noted. The developed resistance results in a loss of all the available post-emergent, systemic herbicides within wheat and canola rotations. Large patches of kochia are often found in southern Saskatchewan and Alberta, particularly along field edges. These patches then give rise to tumbleweeds which disseminate seeds broadly across fields via wind dispersal [35]. As kochia tumbles across the broadly dispersed wild oat infestations, the two weed populations may interact extensively. Little is known how these two weeds may interact, but knowledge may help arm agronomists and researchers in predicting subsequent outcomes to make recommendations to producers.

Both kochia and wild oat are early successional species on the Great Plains of North America, as noted in North Dakota [6]. Early successional species seldom reproduce locally, opting for invading new habitats for open niches [36]. Wali [6] noted regarding remediated mines, kochia was consistently the first weedy vegetation to invade. Kochia persisted into the second year, then declined sharply towards elimination by the third to the fourth year when replaced by annual grasses such as wild oat [6]. Secondary succession within agricultural ecosystems is halted primarily with broad-spectrum herbicides such as glyphosate and glufosinate in canola production.

Previous studies have focused on weeds and crop interspecific competition. Wild oat competitiveness has been studied in wheat [23,24,37,38], canola [25], dry peas [39], sugar beets [40], and barley $[23,41]$. Kochia competitiveness has also been studied in several crops including sunflower [42], sugar beet [43-45], oat [46], wheat, and barley [47]. Studies of interspecific competition between co-occurring weeds such as wild oat and kochia, however, are less common. Their study may provide insight into potential interactions within the weed community to better anticipate community shifts in response to herbicide resistance evolution. As such, the study objective was to assess intraspecies and interspecies competition dynamics between wild oat and kochia, to simulate interactions of a kochia tumbleweed moving through an established wild oat patch. Given this context, autoallelopathy was not considered as kochia will likely not be growing within substantial decaying parent vegetation.

\section{Materials and Methods}

Experiments were conducted at the Saskatoon Research and Development Centre (SRDC) in Saskatoon, SK. The first experiment was conducted at the SRDC research farm greenhouse $\left(52.15^{\circ} \mathrm{N}, 106.58^{\circ} \mathrm{W}\right)$ while the second was conducted at the SRDC station greenhouse $\left(52.14^{\circ} \mathrm{N}, 106.63^{\circ} \mathrm{W}\right)$. Environmental conditions at the SRDC research farm greenhouse included an average daily temperature of $18^{\circ} \mathrm{C}$ and natural light supplemented with artificial lights with a photosynthetic photon flux density (PPFD) of $255 \mu \mathrm{mol} \mathrm{m}{ }^{-2} \mathrm{~s}^{-1}$ at plant level. Environmental conditions at the SRDC station greenhouse were an average 
daily temperature of $17^{\circ} \mathrm{C}$ and natural light supplemented with artificial lights with a PPFD of $190 \mu \mathrm{mol} \mathrm{m}{ }^{-2} \mathrm{~s}^{-1}$ at plant level.

The experimental design was a two-factor factorial arranged as a randomized complete block with four blocks and repeated measures. The first factor was kochia density at 0 , 1 , or 2 plants per pot. The second factor was wild oat density at 0,1 , or 2 plants per pot. The treatment combination which resulted in no plants per pot was not included in the experiment or analysis.

Kochia and wild oat were sown into 121-cell flats filled with potting soil (described below). Kochia seed was from a group 2 and 9 herbicide-resistant parent from Lethbridge, $\mathrm{AB}$, Canada. Wild oat seed was from a Group 1 resistant population from a producer field in Saskatchewan. Seedlings were transplanted into treatment densities upon emergence. An example of planting orientation can be found in Figure 1. Plants were planted into $13 \mathrm{~cm}$ diameter pots filled with bulk mixed potting soil. Potting soil was composed of two bales of Pro-Mix BX (107 L bail ${ }^{-1}$, Premier Tech Horticulture Inc., Rivière-du-Loup, QC, Canada), slow-release fertilizer (4.2 kg, 15-9-12, Osmocote Plus, Everris NA, Dublin, OH, USA), chelated iron (15 g, Dissolvine Iron 13\% EDTA, Nouryon, Amsterdam, The Netherlands), calcium carbonate (2.0 kg, "0" Grind Limestone Ground Powder, Graymont Limited, Richmond, BC, Canada), superphosphate (400 g, 0-45-0, Evergro, Nutrien Solutions, Calgary, AB, Canada), and zinc (7 g, 14\% Zinc Chelate, Plant Products Co. Lt., Leamington ON, Canada). Plants were provided sufficient moisture for growth. The pot size corresponded to an area of $127 \mathrm{~cm}^{2}$. For comparison purposes, the corresponding densities of $1,2,3$, and 4-plant pot $^{-1}$ were $79,158,237$, and 316 plants $\mathrm{m}^{-2}$.
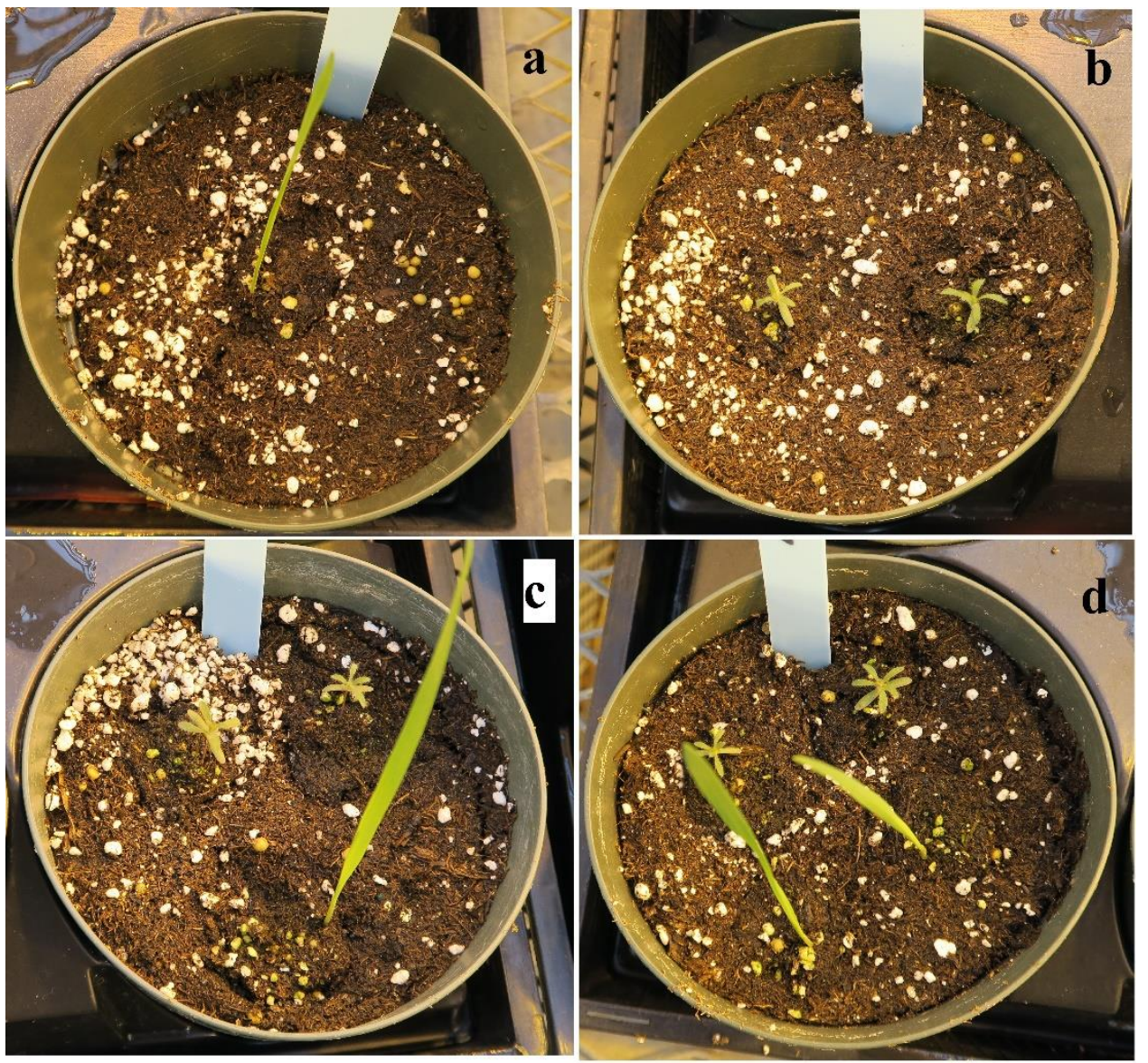

Figure 1. Example planting orientation for the wild oat (Avena fatua) and kochia (Kochia scorpia) competition experiments conducted in 2019 to 2020 in Saskatoon, SK. Treatment combinations resulted in (a) one plant per pot, (b) two plants per pot, (c) three plants per pot, or (d) four plants per pot. The pot tag is $1.5 \mathrm{~cm}$ in width. 
The trial was conducted for 2.5 months (Table 1). Response variables were kochia and wild oat plant heights and biomass. Plant heights were taken approximately halfway through the study and at the end of the study period (Table 1). The end of the study period corresponded with wild oat seed shatter, 81 days after trial initiation (DATI). For kochia, plant heights were taken to the tip of the plant. For wild oat, plant heights were taken from the base to the length of the longest leaf from the base. Biomass was harvested by cutting the plants at the soil surface and drying for 3 days at $65^{\circ} \mathrm{C}$. When two kochia or wild oat plants were within a single experimental unit, their average height or biomass is reported for that treatment.

Table 1. Experimental details for greenhouse kochia and wild oat interference study conducted in Saskatoon, SK in 2019 to 2020 .

\begin{tabular}{|c|c|c|c|c|}
\hline \multirow{2}{*}{ Trial Activity } & \multicolumn{2}{|c|}{ Experiment 1} & \multicolumn{2}{|c|}{ Experiment 2} \\
\hline & Date & DATI * & Date & DATI \\
\hline Seeding & 6 September 2019 & 0 & 6 December 2019 & 0 \\
\hline Transplanting & 24 September 2019 & 11 & 17 December 2019 & 11 \\
\hline Height Timing 1 & 1 November 2019 & 49 & 13 January 2020 & 38 \\
\hline Height Timing 2 & 3 December 2019 & 81 & 25 February 2020 & 81 \\
\hline Biomass & 3 December 2019 & 81 & 25 February 2020 & 81 \\
\hline
\end{tabular}

*DATI = Days after trial initiation.

Data were subjected to ANOVA using the GLIMMIX procedure in SAS (version 9.4, SAS Institute, Cary, NC, USA). Repeated measures were conducted using the random statement, specifying the autoregressive 1 covariance structure. Block and experimental run were considered random effects. Assumptions of normality and constant variance were verified using residual plots. If the constant variance assumption could not be met then a square root transformation was used and back-transformed estimates are reported. Means comparison was conducted using Tukey's honest significance test $(\alpha=0.05)$.

\section{Results}

\subsection{Plant Heights}

Kochia plant heights were impacted by measurement timing $(p<0.001)$, wild oat density $(p<0.001)$, and an interaction between measurement timing and wild oat density $(p=0.0001)$. Kochia plant heights were not affected by kochia density $(p=0.9941)$, kochia density interactions with measurement timing $(p=0.8563)$ or wild oat density $(p=0.5515)$, or the three-way interaction between kochia density, wild oat density, and measurement timing ( $p=0.6995)$. There was no impact of wild oat density on kochia heights at the first measurement timing (38 to 49 DATI), but by the trial end (81 DATI), interspecific interference by wild oat at either density stunted kochia by approximately $37 \%$ (Figure 2).

Experimental runs were analyzed separately for wild oat plant heights due to an ANOVA assumption violation. Wild oat plant height was affected by wild oat density $(p=0.0086)$ and measurement timing $(p<0.0001)$ but not kochia density $(p=0.8465)$ or any main effect interactions $(p>0.05)$ for the first experimental run. Across all planting densities, as expected, wild oat plant heights changed over time, reaching $75 \mathrm{~cm}$ at 49 DATI and $106 \mathrm{~cm}$ at 81 DATI. Across all measurement timings, intraspecific interference was detected using Tukey's mean's comparison, where a single wild oat plant was $95 \mathrm{~cm}$ tall, while when two wild oat plants were grown together, the average height per plant was $86 \mathrm{~cm}$. 


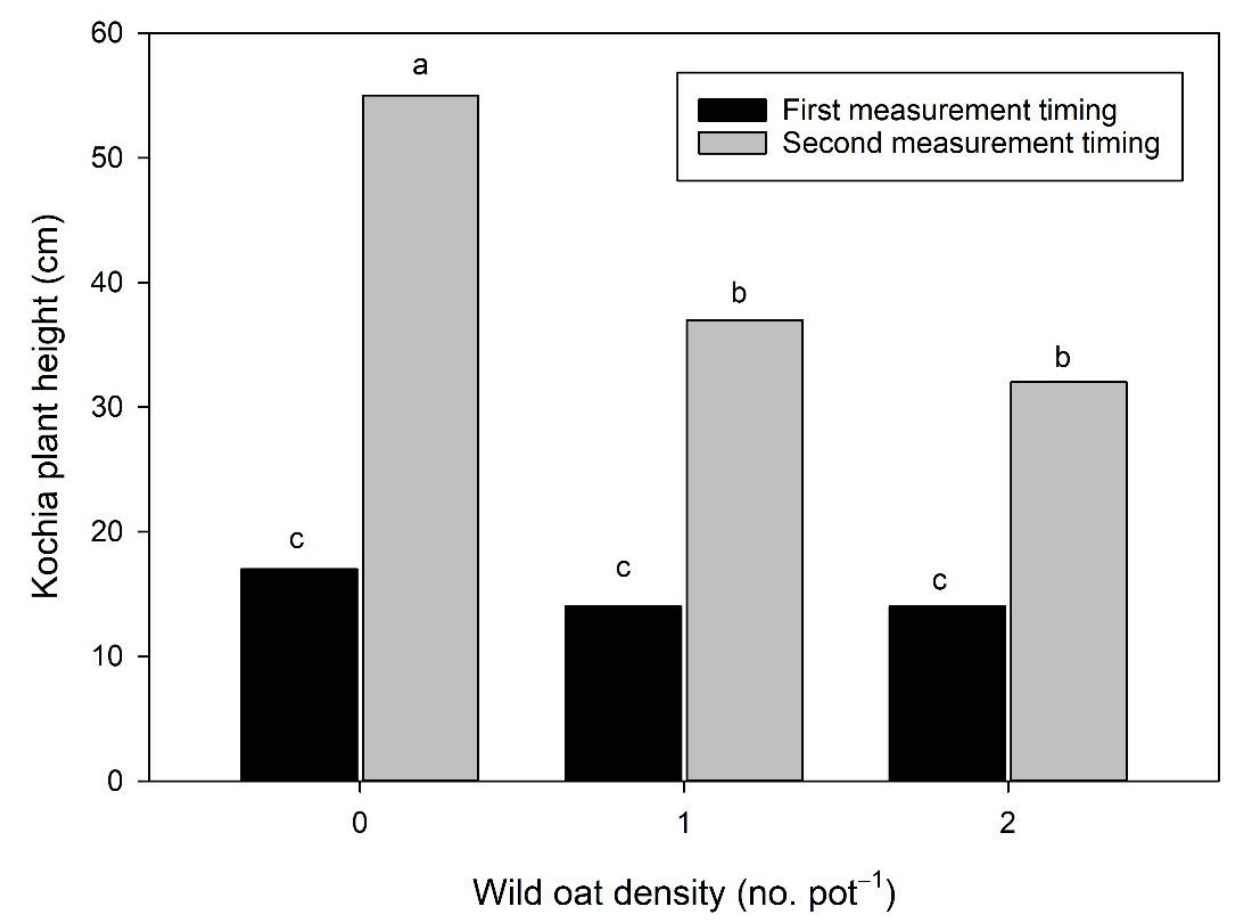

Figure 2. Back transformed least square estimates of kochia (Kochia scoparia) plant heights as impacted by wild oat (Avena fatua) density over time when grown in a greenhouse in Saskatoon, SK, in 2019 to 2020. Plants were grown in $13 \mathrm{~cm}$ diameter round pots filled with potting soil. Data were pooled over two experimental runs. Different letter groups indicate a significant difference using Tukey's honest significance test $(p=0.05)$. Results are pooled for both experimental runs.

Wild oat plant heights were affected by wild oat density $(p=0.0060)$, kochia density $(p=0.0317)$, measurement timing $(p<0.0001)$, and the three-way interaction between wild oat density, kochia density, and measurement timing $(p=0.0047)$ for the second experimental run. For the higher order interaction, as expected, wild oat had demonstrated increased growth at 81 DATI compared to 38 DATI across all treatment combinations (Table 2). There was no impact of either kochia or wild oat densities on wild oat plant heights at the first measurement timing (Table 2). At the trial end (81 DATI), the control (a single wild oat with no competition) was not different from other treatments. One wild oat in competition with two kochia plants did produce an elevated plant height compared to competition between two wild oats, one wild oat and one kochia, and two wild oats and two kochia (Table 2).

Table 2. Wild oat (Avena fatua) plant heights for the second experimental run as impacted by kochia (Kochia scoparia) density, wild oat density, and measurement timing when grown in a greenhouse in Saskatoon, SK in 2019 to $2020^{\mathrm{a}}$.

\begin{tabular}{|c|c|c|c|c|c|}
\hline \multirow{3}{*}{$\begin{array}{c}\text { Kochia Density } \operatorname{Pot}^{-1} \\
0\end{array}$} & \multirow{3}{*}{$\begin{array}{c}\text { Wild Oat Density } \operatorname{Pot}^{-1} \\
1\end{array}$} & \multicolumn{4}{|c|}{ Wild Oat Plant Height (cm) } \\
\hline & & \multicolumn{2}{|c|}{38 DATI $^{b}$} & \multicolumn{2}{|c|}{81 DATI } \\
\hline & & 66 & c & 176 & $\mathrm{ab}$ \\
\hline 0 & 2 & 60 & c & 164 & $\mathrm{~b}$ \\
\hline 1 & 1 & 57 & c & 162 & $\mathrm{~b}$ \\
\hline 1 & 2 & 48 & c & 167 & $\mathrm{ab}$ \\
\hline 2 & 1 & 65 & c & 191 & $\mathrm{a}$ \\
\hline 2 & 2 & 60 & c & 159 & $\mathrm{~b}$ \\
\hline
\end{tabular}

a Plants were grown in $13 \mathrm{~cm}$ diameter round pots filled with potting soil. Different letter groups within or between columns indicate a significant difference using Tukey's honest significance test $(p=0.05) .{ }^{\mathrm{b}}$ DATI $=$ days after trial initiation. 


\subsection{Biomass}

The kochia biomass ANOVA detected an interaction between experimental treatment and experimental run $(p=0.043)$, so experimental runs were analyzed separately for both wild oat and kochia. For the first experimental run, kochia biomass was impacted by kochia density $(p=0.0229)$ and wild oat density $(p<0.0001)$, but there was no interaction between kochia and wild oat densities $(p=0.0913)$. Kochia biomass was reduced by approximately $70 \%$ from wild oat interspecific competition at either density (Figure 3A). Kochia biomass was reduced by $35 \%$ in response to intraspecific competition (Figure $3 \mathrm{~B}$ ).
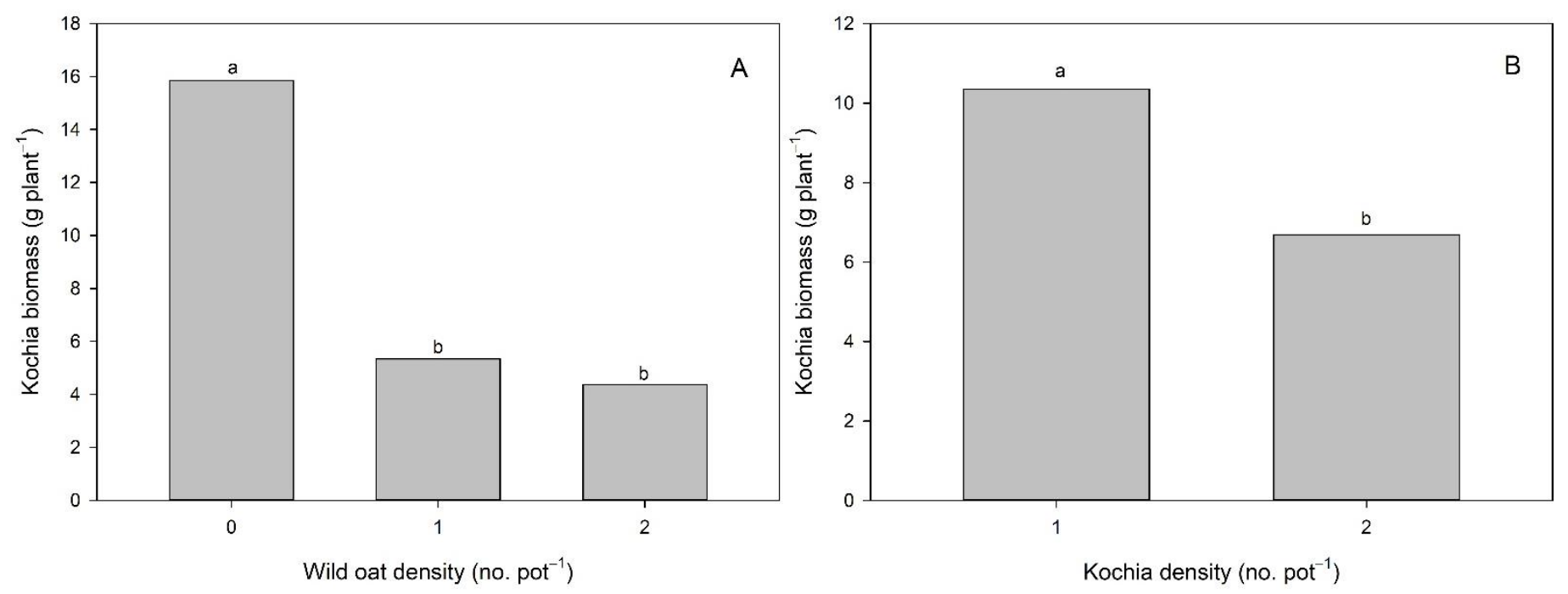

Figure 3. Kochia (Kochia scoparia) biomass in response to wild oat (Avena fatua) and kochia interference for the first experimental run in Saskatoon, SK in 2019. This experiment, only the main effects of (A) wild oat and (B) kochia densities on kochia biomass were significant. Values are least square means. Different letter groups within a panel indicate a significant difference $(\alpha=0.05)$ using Tukey's honest significance test. Plants were grown in $13 \mathrm{~cm}$ diameter round pots filled with potting soil. Biomass was harvested 81 days after trial initiation.

For the second experimental run, kochia biomass was impacted by an interaction between kochia and wild oat densities $(p=0.042)$, as well as an impact of wild oat density $(p<0.001)$ but not kochia density $(p=0.508)$. Kochia biomass was reduced by interspecific competition with wild oat at either density (Figure 4) but there was no difference between wild oat densities.

Wild oat biomass was affected by kochia density $(p=0.0083)$, wild oat density $(p<0.0001)$, and an interaction between kochia and wild oat densities $(p=0.0416)$ for the first experimental run. In the second experimental run, there was no impact of kochia density $(p=0.4654)$ but there was an impact of wild oat density $(p=0.002)$, and no interaction between kochia and wild oat densities $(p=0.4612)$ on wild oat biomass. Kochia only impacted the accumulated biomass of wild oat when there were two per pot (Figure 5) in experiment one. In experiment 2 , wild oat biomass was only impacted by intraspecific competition, where a single wild oat weighed $29.38 \mathrm{~g}$ and competition between two wild oat plants resulted in a significant decrease in the resultant biomass to $21.82 \mathrm{~g}$. 


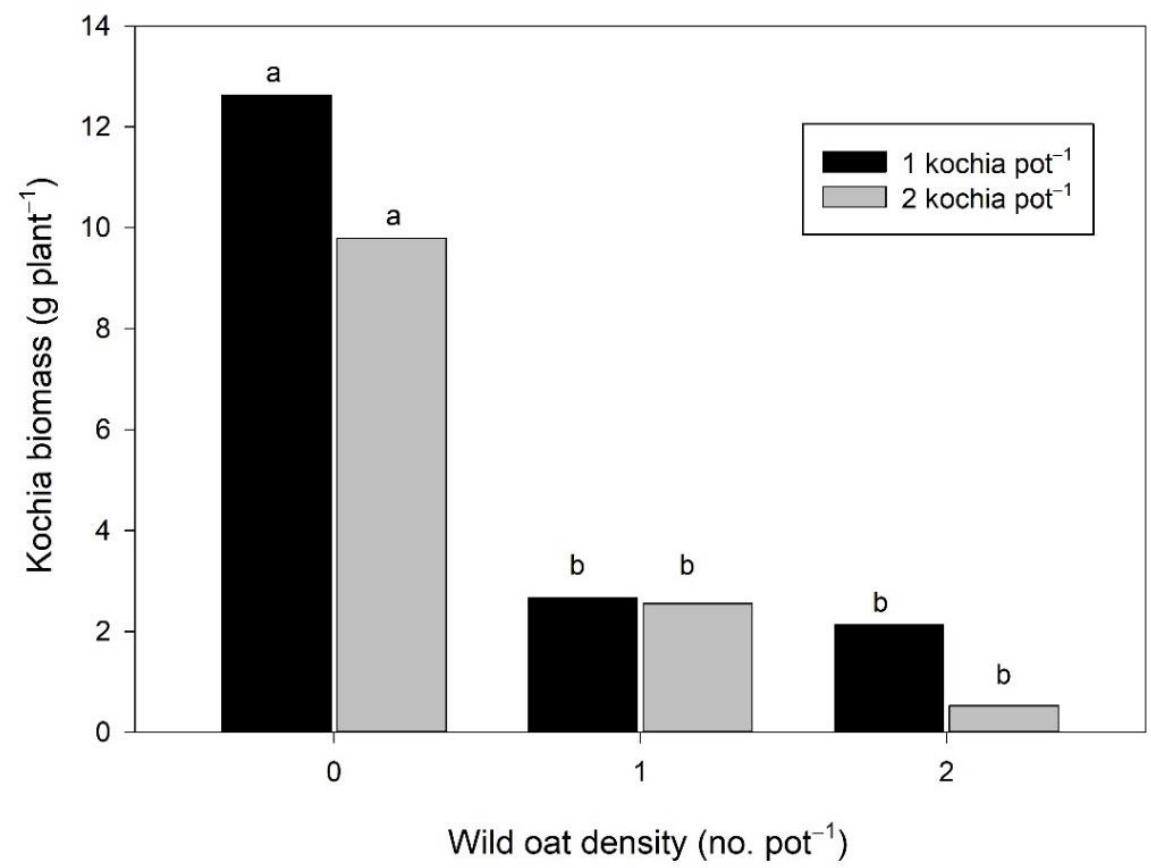

Figure 4. Kochia (Kochia scoparia) biomass in response to wild oat (Avena fatua) and kochia interference for the second experimental run in Saskatoon, SK in 2019. In the second experimental run, there was an interaction between kochia and wild oat densities. Values are least square means. Different letter groupings indicate a significant difference using Tukey's honest significance test $(\alpha=0.05)$. Plants were grown in $13 \mathrm{~cm}$ diameter round pots filled with potting soil. Biomass was harvested 81 days after trial initiation.

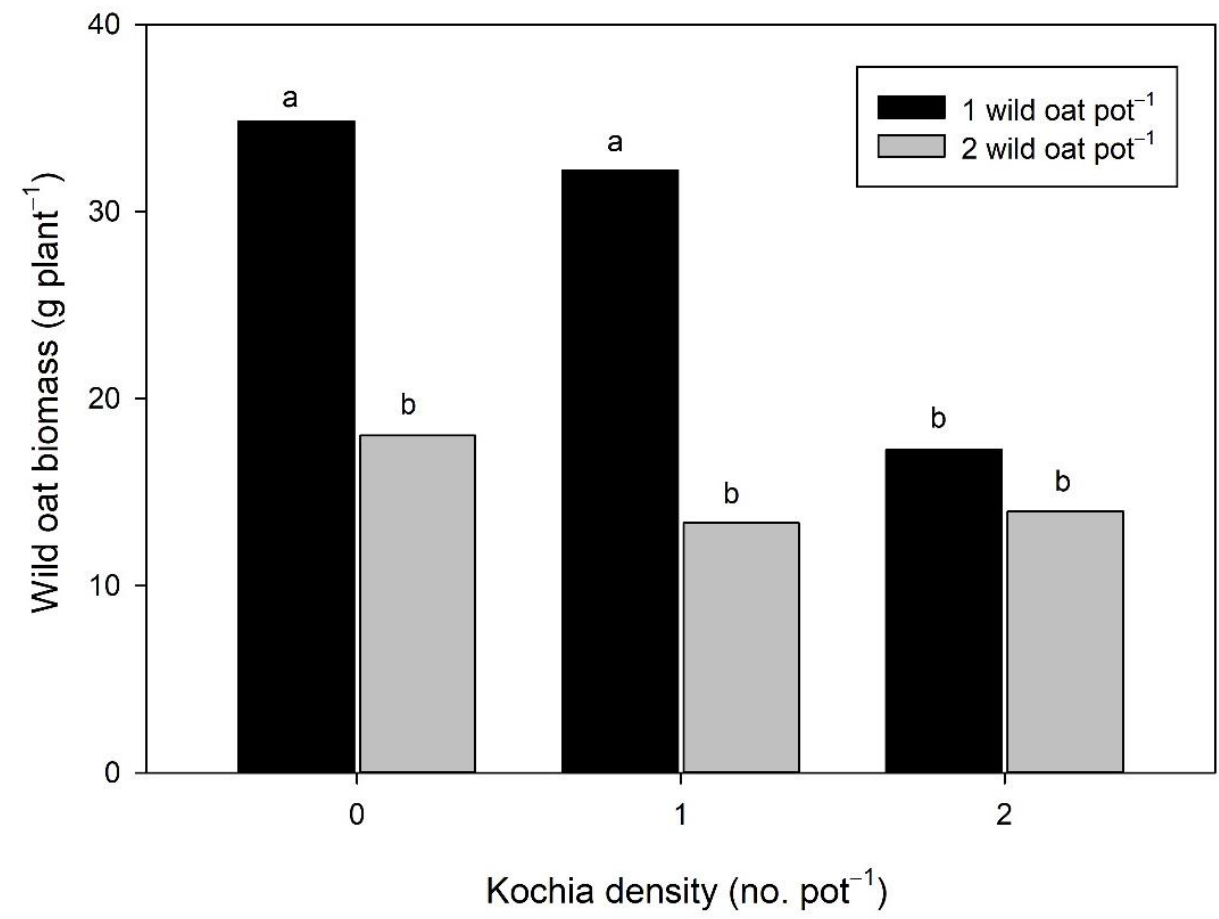

Figure 5. Wild oat (Avena fatua) biomass for the first experimental run as impacted by kochia (Kochia scoparia) and wild oat densities when grown in a greenhouse in Saskatoon, SK in 2019. Plants were grown in $13 \mathrm{~cm}$ diameter round pots filled with potting soil. Biomass was taken at 81 days after trial initiation. Values are least square means. Different letter groups indicate a significant difference using Tukey's honest significance test $(p=0.05)$. 


\section{Discussion}

Wild oat was the dominant competitor compared to kochia, inducing significant reductions in kochia heights and biomass (Figures 2 and 3). Wild oats typically takes 2 to 3 months to reach full maturity after emergence [48] and shed seeds prior to the wheat harvest [49] while kochia typically disperses post-harvest, with observations of nonviable seeds produced around cereal harvest [26]. Such observations are consistent with the current study, as related to comparative plant growth. The current experiment was terminated at the initiation of the seed shatter for wild oat, to characterize the extent of competition in accumulated biomass. Additional field-based research is required to determine the competition-related fecundity and additional impact of various crop plants on this competition dynamic.

With the development of multiple herbicide-resistant kochia biotypes [31,34], kochia may further invade the Moist Mixed Grasslands and Aspen Parkland Ecoregion from the Mixed Grassland Ecoregion [14], increasing both its distribution and field densities. Should this occur, established wild oat infestations are not likely to be displaced in their relative abundance in the weed community and may impede kochia's range expansion, though this requires further study.

While a direct comparison of competition dynamics between weed species is limited, some comparisons have been made with regards to impact on crop species. Sugar beet (Beta vulgaris L.) plant heights were not affected by kochia or wild oat densities [40], indicating sugar beet can withstand wild oat interference. The authors also found that wild oat height was not affected by wild mustard densities but wild mustard interfered more greatly with sugar beet yield than wild oat $\left(0.4\right.$ to 1 plant $\left.\mathrm{m}^{2}\right)$ [40]. This was attributed to light competition above the sugar beet canopy. Selective removal of wild oat in dry pea production resulted in higher yields than selective removal of redstem filaree in Alberta [39].

Intraspecific kochia competition, from 6 to 30 plants $\mathrm{m}^{-2}$, did not reduce plant heights during 3 of 4 field studies [46]. Kochia intraspecific competition belowground was demonstrated to be symmetric, that is, not exacerbated by the size of the neighboring plant [50]. Kochia height was not impacted by kochia or green foxtail density in sugar beet [45]. Kochia interference was found to be five-times greater than green foxtail interference on sugar beet yield under well-watered and fertilized conditions [45]. Similarly to the current findings with wild oat, kochia competition did not impact tame oat plant heights or 500-kernel weight, but did reduce yield at a kochia density of 30 plants $\mathrm{m}^{2}$ [46].

\section{Conclusions}

Overall, wild oat was the dominant competitor when growing in a mixed community with kochia when factors of allelopathy were removed. Kochia did not consistently impact wild oat plant heights while wild oat did consistently stunt kochia (Figure 2, Table 2). Wild oat biomass was susceptible to interference, primarily intraspecific, but a combination of interspecific and intraspecific competition did reduce wild oat biomass on one experimental run. Kochia biomass was impacted primarily from wild oat competition, but a reduction in kochia biomass was observed for one instance. This scenario simulated the resultant condition of kochia tumbleweed dispersal through wild oat patches. Additional research is required to account for allelopathy as it plays a dominant role for established kochia patches [5,6] even though it demonstrates auto-allelopathy [27]. Given the wind-driven tumbleweed dispersal for kochia [51], it is possible that some degree of niche differentiation may occur spatially within the weed community, with kochia occupying field borders.

Funding: This research received no external funding.

Institutional Review Board Statement: Not applicable.

Informed Consent Statement: Not applicable.

Data Availability Statement: The data presented in this study are available on request from the corresponding author. 
Acknowledgments: The author acknowledges the technical support provided by Taylor Kaye, Sarah Vogt, and the greenhouse staff at the Saskatoon Research and Development Centre.

Conflicts of Interest: The author declares no conflict of interest.

\section{References}

1. Statistics Canada. Table 32-10-0359-01 Estimated Areas, Yield, Production, Average Farm Price and Total Farm Value of Principal Field Crops, in Metric and Imperial Units. Available online: https:/ / doi.org/10.25318/3210035901-eng (accessed on 2 September 2020).

2. Awada, L.; Gray, R.S.; Nagy, C. The Benefits and Costs of Zero Tillage RD\&E on the Canadian Prairies. Can. J. Agric. Econ. 2016, 64, 417-438. [CrossRef]

3. Anonymous. 2019 Guide to Crop Protection For the Chemical Management of Weeds, Plant Diseases, and Insects; Saskatchewan Ministry of Agriculture: Regina, SK, Canada, 2019.

4. Heap, I. The International Survey of Herbicide Resistant Weeds; 2016. Available online: www.weedscience.org (accessed on 2 September 2020).

5. Iverson, L.R.; Wali, M.K. Reclamation of coal mined lands: The role of Kochia scoparia and other pioneers in early succession. Reclam. Reveg. Res. 1982, 1, 123-160.

6. Wali, M.K. Ecological succession and the rehabilitation of disturbed terrestrial ecosystems. Plant Soil 1999, 213, 195-220. [CrossRef]

7. Thompson, H.N. Farm Weeds and How to Control Them; Government of the Province of Saskatchewan: Regina, SK, Canada, 1916; p. 72.

8. Thomas, A.G. 1976 Weed Survey of Cultivated Land in Saskatchewan; Agriculture Canada, Regina Research Station: Regina, SK, Canada, 1976; p. 93.

9. Thomas, A.G. 1977 Weed Survey of Cultivated Land in Saskatchewan; Agriculture Canada, Regina Research Station: Regina, SK, Canada, 1977; p. 103.

10. Thomas, A.G. Weed Survey System Used in Saskatchewan for Cereal and Oilseed Crops. Weed Sci. 1985, 33, 34-43. [CrossRef]

11. Thomas, A.G.; Wise, R.F. Weed Survey of Saskatchewan: Cereal and Oilseed Crops 1986; Agriculture Canada, Regina Research Station: Regina, SK, Canada, 1987; p. 251.

12. Thomas, A.G.; Wise, R.F.; Frick, B.L.; Juras, L.T. Saskatchewan Weed Survey: Cereal, Oilseed and Pulse Crops 1995; Agriculture and Agri-Food Canada, Saskatoon Research Station: Regina, SK, Canada, 1996; p. 419.

13. Leeson, J.Y.; Thomas, A.G.; Brenzil, C.A. Saskatchewan Weed Survey: Cereal, Oilseed, and Pulse Crops 2003; Agriculture and Agri-Food Canada, Saskatoon Research Centre: Regina, SK, Canada, 2003; p. 342.

14. Leeson, J.Y. Saskatchewan Weed Survey of Cereal, oilseed and Pulse Crops in 2014 and 2015; Agriculture and Agri-Food Canada, Saskatoon Research Centre: Regina, SK, Canada, 2016; p. 356.

15. Leeson, J.Y.; Thomas, A.G.; Sheard, J.W. Weed Distribution Across Field Boundaries Adjacent to Roadsides. In Field Boundary Habitats: Implications for Weed, Insect and Disease Management; Thomas, A.G., Ed.; Canadian Weed Science Society: Sainte-Anne-de-Bellevue, QC, Canada, 2005; pp. 185-200.

16. Naylor, J.M.; Jana, S. Genetic adaptation for seed dormancy in Avena fatua. Can. J. Bot. 1976, 54, 306-312. [CrossRef]

17. Jana, S.; Achar, S.N.; Naylor, J.M. Dormancy studies in seed of Avena fatua. 10. On the inheritance of germination behaviour. Can. J. Bot. 1979, 57, 1663-1667. [CrossRef]

18. Jana, S.; Upadhyana, M.K.; Achar, S.N. Genetic basis of dormancy and differential response to sodium azide in Avena fatua seeds. Can. J. Bot. 1988, 66, 635-641. [CrossRef]

19. Gallandt, E.R.; Fuerst, E.P.; Kennedy, A.C. Effect of tillage, fungicide seed treatment, and soil fumigation on seed bank dynamics of wild oat (Avena fatua). Weed Sci. 2004, 52, 597-604. [CrossRef]

20. Heap, I.M.; Murray, B.G.; Loeppky, H.A.; Morrison, I.N. Resistance to Aryloxyphenoxypropionate and Cyclohexanedione Herbicides in Wild Oat (Avena fatua). Weed Sci. 1993, 41, 232-238. [CrossRef]

21. Beckie, H.J.; Thomas, A.G.; Légère, A.; Kelner, D.J.; Van Acker, R.C.; Meers, S. Nature, Occurrence, and Cost of Herbicide-Resistant Wild Oat (Avena fatua) in Small-Grain Production Areas. Weed Technol. 1999, 13, 612-625. [CrossRef]

22. Beckie, H.J.; Warwick, S.I.; Sauder, C.A. Basis for Herbicide Resistance in Canadian Populations of Wild Oat (Avena fatua). Weed Sci. 2012, 60, 10-18. [CrossRef]

23. Bell, A.R.; Nalewaja, J.D. Competition of Wild Oat in Wheat and Barley. Weed Sci. 1968, 16, 505-508. [CrossRef]

24. O'Donovan, J.T.; de Remy, E.A.; O'Sullivan, P.A.; Dew, D.A.; Sharma, A.K. Influence of the Relative Time of Emergence of Wild Oat (Avena fatua) on Yield Loss of (Hordeum vulgare) and Wheat (Triticum aeiticum). Weed Sci. 1985, 33, 498-503. [CrossRef]

25. Zand, E.; Beckie, H.J. Competitive ability of hybrid and open-pollinated canola (Brassica napus) with wild oat (Avena fatua). Can. J. Plant Sci. 2002, 82, 473-480. [CrossRef]

26. Friesen, L.F.; Beckie, H.J.; Warwick, S.I.; Van Acker, R.C. The biology of Canadian weeds. 138. Kochia scoparia (L.) Schrad. Can. J. Plant Sci. 2009, 89, 141-167. [CrossRef]

27. Lodhi, M.A.K. Germination and decreased growth of Kochia scoparia in relation to its autoallelopathy. Can. J. Bot. 1979, 57, 1083-1088. [CrossRef]

28. Braidek, J.T.; Fedec, P.; Jones, D. Field survey of halophytic plants of disturbed sites on the canadian prairies. Can. J. Plant Sci. 1984, 64, 745-751. [CrossRef] 
29. Hall, L.M.; Beckie, H.J.; Low, R.; Shirriff, S.W.; Blackshaw, R.E.; Kimmel, N.; Neeser, C. Survey of glyphosate-resistant kochia (Kochia scoparia L. Schrad.) in Alberta. Can. J. Plant Sci. 2014, 94, 127-130. [CrossRef]

30. Beckie, H.J.; Gulden, R.H.; Shaikh, N.; Johnson, E.N.; Willenborg, C.J.; Brenzil, C.A.; Shirriff, S.W.; Lozinski, C.; Ford, G. Glyphosate-resistant kochia (Kochia scoparia L. Schrad.) in Saskatchewan and Manitoba. Can. J. Plant Sci. 2015, 95, 345-349. [CrossRef]

31. Beckie, H.J.; Hall, L.M.; Shirriff, S.W.; Martin, E.; Leeson, J.Y. Triple-resistant kochia [Kochia scoparia (L.) Schrad.] in Alberta. Can. J. Plant Sci. 2019, 99, 281-285. [CrossRef]

32. Morrisson, I.N.; Devine, M.D. Herbicide resistance in the Canadian prairie provinces: Five years after the fact. Phytoprotection 1994, 75, 5-16. [CrossRef]

33. Beckie, H.J.; Warwick, S.I.; Sauder, C.A.; Lozinski, C.; Shirriff, S. Occurrence and Molecular Characterization of Acetolactate Synthase (ALS) Inhibitor-Resistant Kochia (Kochia scoparia) in Western Canada. Weed Technol. 2011, 25, 170-175. [CrossRef]

34. Beckie, H.J.; Blackshaw, R.E.; Low, R.; Hall, L.M.; Sauder, C.A.; Martin, S.; Brandt, R.N.; Shirriff, S.W. Glyphosate- and Acetolactate Synthase Inhibitor-Resistant Kochia (Kochia scoparia) in Western Canada. Weed Sci. 2013, 61, 310-318. [CrossRef]

35. Kumar, V.; Jha, P. Growth and Reproduction of Glyphosate-Resistant and Susceptible Populations of Kochia scoparia. PLoS ONE 2015, 10, e0142675. [CrossRef] [PubMed]

36. Horn, H.S. The Ecology of Secondary Succession. Annu. Rev. Ecol. Syst. 1974, 5, 25-37. [CrossRef]

37. Carlson, H.L.; Hill, J.E. Wild Oat (Avena fatua) Competition with Spring Wheat: Plant Density Effects. Weed Sci. 1985, 33, $176-181$. [CrossRef]

38. Cudney, D.W.; Jordan, L.S.; Hall, A.E. Effect of Wild Oat (Avena fatua) Infestations on Light Interception and Growth Rate of Wheat (Triticum aestivum). Weed Sci. 1991, 39, 175-179. [CrossRef]

39. Harker, K.N.; Blackshaw, R.E.; Clayton, G.W. Wild Oat (Avena fatua) vs. Redstem Filaree (Erodium cicutarium) Interference in Dry Pea. Weed Technol. 2007, 21, 235-240. [CrossRef]

40. Mesbah, A.; Miller, S.D.; Fornstrom, K.J.; Legg, D.E. Wild Mustard (Brassica kaber) and Wild Oat (Avena fatua) Interference in Sugarbeets (Beta vulgaris L.). Weed Technol. 1995, 9, 49-52. [CrossRef]

41. O'Donovan, J.T.; Harker, K.N.; Clayton, G.W.; Hall, L.M. Wild Oat (Avena fatua) Interference in Barley (Hordeum vulgare) is Influenced by Barley Variety and Seeding Rate. Weed Technol. 2000, 14, 624-629. [CrossRef]

42. Durgan, B.R.; Dexter, A.G.; Miller, S.D. Kochia (Kochia scoparia) Interference in Sunflower (Helianthus annuus). Weed Technol. 1990, 4, 52-56. [CrossRef]

43. Weatherspoon, D.M.; Schweizer, E.E. Competition Between Kochia and Sugarbeets. Weed Sci. 1969, 17, 464-467. [CrossRef]

44. Weatherspoon, D.M.; Schweizer, E.E. Competition Between Sugarbeets and Five Densities of Kochia. Weed Sci. 1971, 19, 125-128. [CrossRef]

45. Mesbah, A.; Miller, S.D.; Fornstrom, K.J.; Legg, D.E. Kochia (Kochia scoparia) and Green Foxtail (Setaria viridis) Interference in Sugarbeets (Beta vulgaris). Weed Technol. 1994, 8, 754-759. [CrossRef]

46. Manthey, F.A.; Hareland, G.A.; Zollinger, R.K.; Huseby, D.J. Kochia (Kochia scoparia) Interference with Oat (Avena sativa). Weed Technol. 1996, 10, 522-525. [CrossRef]

47. Fischer, A.J.; Messersmith, C.G.; Nalewaja, J.D.; Duysen, M.E. Interference between Spring Cereals and Kochia scoparia Related to Environment and Photosynthetic Pathways. Agron. J. 2000, 92, 173-181. [CrossRef]

48. Sharma, M.P.; Born, W.H.V. The Biology of Canadian Weeds. 27. Avena fatua L. Can. J. Plant Sci. 1978, 58, 141-157. [CrossRef]

49. Shirtliffe, S.J.; Entz, M.H.; Van Acker, R.C. Avena fatua Development and Seed Shatter as Related to Thermal Time. Weed Sci. 2000, 48, 555-560. [CrossRef]

50. Weiner, J.; Wright, D.B.; Castro, S. Symmetry of Below-Ground Competition between Kochia scoparia Individuals. Oikos 1997, 79, 85-91. [CrossRef]

51. Becker, D.A. Stem Abscission in Tumbleweeds of the Chenopodiaceae: Kochia. Am. J. Bot. 1978, 65, 375-383. [CrossRef] 